\title{
Foreign Aid, Domestic Savings and Economic Growth in Selected MENA Countries
}

\author{
Mahmoud Mohammed Sabra (Corresponding author) \\ Assistant Prof. of Economics, Economic Department \\ Faculty of Economics and Administrative Sciences \\ Al Azhar University Gaza, Palestine, P. O. Box 1277 \\ E-mail: mmsabra@gmail.com
}

Abdel Hakeem Ahmad Eltalla

Faculty of Business and Finance, Alaqsa University, Gaza, Palestine

E-mail: hakeemeltalla@hotmail.com

Received: March 24, 2016

Accepted: April 17, 2016

doi:10.5296/ber.v6i1.9204

URL: http://dx.doi.org/10.5296/ber.v6i1.9204

\begin{abstract}
Foreign aid can have either a positive or a negative impact on economic growth. The role of foreign aid in supporting growth by completing domestic savings has been a subject of substantial argument. In this study, we explore the role of foreign aid, trade openness, investment, domestic savings and economic growth in eight MENA countries (Morocco, Algeria, Egypt, Palestine, Syria, Jordan, Lebanon and Tunisia) for the period from 1977 to 2013. The estimation has been done using simultaneous equation model and dynamic panel data system analysis. A negative relationship is found between economic growth and foreign aid. The negative impact of foreign aid on economic growth could be due to presence of Dutch disease and bad policy environment. In addition, foreign aid seems to crowd out domestic savings rather than complementing it. The effects of trade openness and domestic investment on economic growth are significantly positive.
\end{abstract}

Keywords: Foreign Aid; Domestic Savings; Economic Growth; Panel Data Models; MENA countries.

JEL classification: F43, F35, E21, C33, C23 


\section{Introduction}

Foreign aid in poor countries has developed into an essential source of economic development and growth. The modest foreign exchange revenues entail less funding for infrastructure projects and social development. Economies that have positive foreign aid experience realized greater human capital growth, more rapid capital accumulation and enhanced welfare (Chowdhury and Garonna 2007). A basic belief for the supporters of foreign aid is that it assists poor countries in attaining higher levels of economic growth by eliminating the difference between saving and investment. Without foreign aid, domestic resources of the aid recipient countries will not utilize. Moreover, foreign aid closes the foreign exchange and the saving gap, due to the lack of foreign currency. Therefore, foreign aid is vital for economic growth in developing economies. Although, most of foreign aid aimed to support economic growth and increase the welfare, there is substantial discussion over the effectiveness of foreign aid. The Empirical studies found mixed results. There is evidences show that foreign capital inflow support economic growth, and other evidences against the theoretical opinion about the effect of foreign capital inflows. Papanek (1973), Gupta and Islam (1982), Dalgaard et al. (2004), found a positive effect of aid on economic growth. Opponent of foreign aid have emphasized the harmful consequence of foreign aid, which in various economies increased non-development spending. In addition, political volatility, repeated policy variations, erroneous public sector priorities and ineffectiveness of institutions reduce the effect of foreign aid on economic growth and poverty reduction. Burnside and Dollar (2000) found a negative impact of aid on economic growth. In addition, aid may has a strong impact on reducing savings, enhancing more consumption and causing Dutch disease, which appreciate currency, increases inflation, raising non-tradable goods prices, moving efficient resources from tradable sectors to non tradable sectors, reducing exports, enforcing more imports (as a result of increasing wages in non tradable sectors and reducing local production), and causing more need of aid to finance imports, which known as aid dependency, Sabra and Sartawi, (2015).

Economic Growth differs between countries and regions. The growth is related to features of the regions such as population growth and investment in capital both physical and human, flow of foreign capital, inflation and unemployment rates. The economic growth in the MENA countries has been affected by high population growth and unemployment rates; foreign aid and influence of the government over the economic sectors.

In this study we empirically examine the impact of foreign aid on domestic savings and economic growth and whether Dutch disease stands or not, which is in the core of developmental studies nowadays. Our empirical work is done in eight MENA countries using different methods, which are two stage least squares and dynamic panel data analysis. These countries are Morocco, Algeria, Egypt, Palestine, Syria, Jordan, Lebanon and Tunisia, and we run the estimation using the available data for period 1977 to 2013, according the availability of data from World Bank database. In fact, this work shows aid developmental influence on the area.

We proceed as follows: in the next section we review the literature, then we present the 
methodology and data, then we show estimation results and finally we conclude.

\section{Literature Review}

Whether foreign aid is effective in supporting economic growth and development in developing countries or not is an open question. Studies that found negative relations between foreign aid and economic growth claim that foreign aid receipt countries increase consumption from capital inflow. That reduces savings and lead to slow economic growth or in other words, economic growth would be higher without aid or with reducing aid or increasing efficient aid. High capital inflow reduces domestic saving or may be savings become negative. Therefore, domestic savings is the function of national income and foreign capital inflows. The negative relation between foreign aid and economic growth may be the result economic policy environments, government intervention, business cycles, and reliability of foreign aid inflows in the recipient poor countries. Hadjimichael et al. (1995) found that the effect of foreign aid is negative for savings Sub-Saharan Africa. Gupta and Islam (1982) found that there is a negative effect of foreign aid on savings in aid recipient countries. Balde (2011) found that foreign aid did not promote economic growth in Sub-Sahara Africa. Rajan and Subramanian (2008) found that foreign aid does not support economic growth, instead, foreign aid hinder economic growth by reducing the domestic saving rate. In addition, theory suggests normally a positive linkage between aid and exports where aid reduces trade barriers and can establish to long-term trade relationships, which enforcing more trade. Sabra (2013) suggests that $1 \%$ increase in aid is associated with an increase in donor exports of goods from $.96 \%$ to $1.7 \%$ of aid to the Arab MENA countries, which are the recipient countries. This may hinder the growth and formulates indirect negative relationship between aid and economic growth.

Morrissey (2001) indicated that foreign aid can enhance economic growth by intensify investment in physical and human capital and the ability to import capital goods. In addition, foreign aid is linked to technology transfer that improves productivity and enhances endogenous technical change. Fayissa and El-Kaissy (1999), in a study of 77 countries found that foreign aid positively impacts economic growth in developing countries. This is coherent with theory of foreign aid, which affirms that foreign aid development enhances economic growth by increasing domestic capital formation. Burnside and Dollar (2000) found the positive effect of foreign aid in developing economies in existence of careful polices. Chong et al. (2009) found important impact of foreign aid on poverty alleviation. In addition, they found high-quality institutions are essential for foreign aid to assist the poor. In fact, the concept behind the positive impact of aid on growth is that aid can fill both investment and resources gaps where its complement savings and increases investment and capital accumulation. Therefore, foreign aid has positive impacts only in those economies that have good fiscal, monetary and trade policies, Burnside and Dollar (2000), which means that good economic policy pre-requested for aid effectiveness, Murshed and Khanaum (2014).

Basnet (2013) examined the role of foreign aid on savings and economic growth in South Asian countries by utilizing a simultaneous equation system. He found that foreign aid enhances economic growth in five South Asian countries and foreign aid adversely influences 
domestic savings during the study period. The positive impact of foreign aid on economic growth might be counterbalance by the negative impact on domestic saving. Djankov et al. (2006) found that foreign aid has a negative effect on economic growth by decreasing investment and escalating government expenditure. Burke and Ahmadi-Esfahani (2006) found that there is no significant relationship between foreign aid and economic growth. They empirically examined the impact of foreign aid on growth by utilizing data from 1970 to 2000 and a simultaneous equation model in three Asian countries, Indonesia, the Philippines and Thailand. In addition, McGillivray, et al. (2006) indicates that aid has a decreasing return, (namely, that each additional dollar of aid has a lower (positive) impact on growth than the preceding dollar). Therefore, aid impacts positively on growth when it has not an adverse impact on local investment and domestic savings. Finally, aid impact on growth is considered the main driver to developmental effects such as poverty alleviation, but such goals remain depend on justice allocation of aid across economic sectors, geographical regions, types of government expenditure and approach to poverty.

Djankov, et al. (2006) results show that aid has a negative direct impact on economic growth, and it does not increase investment, meanwhile, aid has a positive impact on government expenditure. They argue that why aid increases government spending and does not induce investment. This is under a hypothesis that easy resources such as aid may induce rent-seeking activities among parties in power, which imply non-productive use of resources that impacts negatively on investment as a consequence. Therefore, aid impact on growth is subject to aid spending behaviour or allocation between productive or non-productive sectors. Neanidis and Varvarigos (2005), found that allocating aid to productive and non-productive sectors impacts positively and negatively on growth, respectively.

\section{Methodology and Data}

\subsection{Two Stage Least Squares Estimation}

This paper uses unbalanced panel data of eight MENA countries (Morocco, Algeria, Egypt, Palestine1, Syria, Jordan, Lebanon and Tunisia) for the period 1977 to 2013 according the availability of data from World Bank database. The model based on an economic growth equation and a saving equation. Estimation of economic growth and saving equations individually might endure simultaneous equations bias due to some of the explanatory variables might not be truly exogenous. Consequently, we estimate the equations of economic growth and saving equations simultaneously. Equations 1 and 2 are used in the simultaneous analysis. This model is familiar in the literature (Burke and Ahmadi-Esfahani, 2006; Basnet, 2013).

Work that measured aid impact on growth using a single linear regression equation that relates growth to savings, aid inflows and other variables. A significant weakness of this technique is the failure to consider the interconnection between growth and savings and the fact that explanatory variables, including aid and government expenditure are likely to be jointly determined. Therefore, the total impact of aid on growth, including each direct impact,

\footnotetext{
${ }^{1}$ Data available for Palestine from year 1994, and for Lebanon from1990.
} 
and the impact of aid on savings, can only be adequately captured in multiple-equation models, Burke and Ahmadi-Esfahani, (2006). They indicate that the estimation of a single-equation model by ordinary least-squares (OLS), as done by some others, is likely to produce biased and inconsistent parameter estimates. In addition, the problems arising from simultaneity bias in single-equation estimation of the aid-growth relationship, and the merits of simultaneous-equation estimation.

The two-equation model avoids the simultaneity bias occurred in single-equation models. In addition, two-equation model allows for jointly determination of both economic growth and domestic savings. This specification also allows testing Griffin hypothesis (1970) states that foreign aid is ineffective in part because it displaces domestic savings, Burke and Ahmadi-Esfahani, (2006).

$$
\ln \text { GDPC }=\beta_{0}+\beta_{1} \ln \text { AID }+\beta_{2} \ln \text { SAV }+\beta_{3} \ln \text { OPEN }+\beta_{4} \ln \text { FD }+\epsilon \quad \text { Equation } 1
$$

$$
\ln \text { SAV }=\alpha_{0}+\alpha_{1} \ln \text { AID }+\alpha_{2} \ln \text { GDPC }+\alpha_{3} \ln \text { OPEN }+\alpha_{4} \ln \text { INV }+v \text { Equation } 2
$$

Where: GDPC is GDP per capita, which is GDP at constant 2005 prices divided by population, this is the proxy of economic growth. Country size proxies by population which may negatively related to economic growth. Hence, we prefer GDP per capita because it takes population under consideration. AID is net official development assistance and official aid received. SAV is the gross domestic saving. OPEN is the trade openness measured by the sum of exports plus imports as a share of GDP. INV is the gross capital formation in constant prices. FD is fiscal discipline which is the general government final consumption expenditure, and $\epsilon$ and $v$ are error terms. The parameters $\beta_{1}, \beta_{2}, \beta_{3}$ and $\beta_{4}$ represent the elasticities of GDPC with respect to AID, SAV, OPEN and FD. The rationale behind controlling fiscal discipline in our model is that there has always been controversy over the appropriate use of aid. The government of recipient countries uses the aid fund in some other areas other than for the purpose it is given. The government consumption is a proxy for fiscal discipline which includes all government current expenditures for purchases of goods and services and most expenditure on national defence and security. In addition, government expenditure is an important explanatory variable of economic growth, and a source of economic growth, Barro, (1990). Trade openness (open) is a policy variable that is believed to have great effect on growth due to the exploitation of resources and economies of scale. Our interest is whether foreign aid supplements domestic savings to increase gross investment in the economy. Therefore, including domestic investment as an explanatory variable is appropriate. Economic growth positively related to domestic investment. The data source for all the variables is from World Development Indicators of the World Bank. All variables are taken in logarithm. We use the variables in algorithm to reduce multicollinearity. Finally, we use STATA program in our analysis. 


\subsection{Generalized Method of Moments Estimation GMM}

In addition, we use the dynamic panel data GMM systems approach which estimates the parameters from a system of equations. GMM estimation is common approach in empirical work with dynamic panel regression (Arellano and Bond, 1991).

Standard estimators for the static panel data model, which control for the existence of individual effects, are the Fixed Effects Model (FEM) and Random Effects Model (REM) approaches. The econometric analysis with these two models addresses several biases, these biases related to heterogeneity across countries and time. The problem with standard FEM is that, it cannot estimate parameters such as time invariant. On other hand, the problem of standard REM is the biases caused of endogeneity problem due to the potential correlation between one or several explanatory variables and the residuals. However, choosing among the FEM and REM estimator rests on an all or nothing decision with respect to the assumed correlation of right hand side variables (explanatory variables) with the error term. In empirical applications, the truth may often lie in between these two extremes, Mitze (2010). The GMM system technique has been recently widely used in the estimation of dynamic panel data models, and in the empirical analysis of international capital flow. The first differenced model uses lagged levels of dependent variables as instruments for the lagged difference of both variables, and the level model uses lagged differences of dependent variable as instruments for the lagged level of dependent variable first (similarly for the other dependent variable). Second, it uses the difference instrumental variables in the model (Arellano and Bover, 1995; Arellano and Bond 1998; Blundell and Bond, 1998). For the dynamic analysis, we use Arellano-Bover; Blundell-Bond method, which is the Dynamic Panel Data System. This is important for the panel data analysis which widely used in the empirical studies. It shows the transversely connection between the equations in the areas and time zone stated before. Equations 3 and 4 are used in the dynamic analysis.

$$
\begin{aligned}
& \Delta \ln \text { GDPC }=\beta_{0}+\beta_{1} \Delta \ln \text { GDPC }_{t-1}+\beta_{2} \Delta \ln A I D+\beta_{3} \Delta \ln \text { SAV }+\beta_{4} \Delta \ln \text { OPEN } \\
& +\Delta \ln \mathbf{F D}+\mu+\Delta v_{t}
\end{aligned}
$$

$$
\begin{aligned}
& \Delta \ln \mathrm{SAV}=\alpha_{0}+\alpha_{1} \Delta \ln \mathrm{SAV}_{t-1}+\alpha_{2} \Delta \ln \mathrm{AID}+\alpha_{3} \Delta \ln \mathrm{GDPC}+\alpha_{4} \Delta \ln \text { OPEN }+ \\
& \begin{array}{ll}
\alpha_{5} \Delta \ln \operatorname{INV}+\mu+\Delta v_{t} & \text { Equation } 4
\end{array}
\end{aligned}
$$

In GDPCt-1 and In SAVt-1 are the lagged variables of both dependent variables. These lagged independent variables are strongest explanatory variables can explain the dependent variables. $\mu$ represents the unobserved country specific effects, and $v_{t}$ is the standard error.

\section{The Simulation and Empirical Results}

The two stage least squares estimation of equations one and two are presented in Table 1 . The findings offer adequate evidence to decide that foreign aid has a negative effect on growth and domestic savings. The effect of foreign aid on both growth and domestic savings is negative and statistically significant at the $1 \%$ level. The results imply that a $1 \%$ increase in foreign aid is estimated to decrease growth by $0.29 \%$ and reduce domestic savings by $0.15 \%$ 
for the eight MENA countries (Morocco, Algeria, Egypt, Palestine, Syria, Jordan, Lebanon and Tunisia) over the period 1977 to 2013. The findings from model one shows that domestic savings effect on the economic growth of the eight countries statistically significant at the $1 \%$ level. Openness has a positive relationship with the rate of economic growth. Government expenditure which is a proxy for fiscal discipline has a positive relationship to growth. The impact of government expenditure is significant at the $1 \%$ level. The results show that a $1 \%$ increase in of government expenditure is estimated to increase economic growth by $0.79 \%$, which reflects the main source of economic growth. The findings from model 2 show that foreign aid negatively influences domestic saving in the eight MENA countries during the study period. This result show that foreign aid does not complements domestic savings. Foreign aid is crowding out domestic savings in the eight MENA countries. In addition, this illustrate that foreign aid recipient countries do not increase taxes nevertheless boost consumption from external funds which end in lower saving and thus lower growth.

Table 1. Two stage least squares estimation

\begin{tabular}{|l|l|l|c|l|l|l|l|}
\hline & Constant & AID & GDPC & SAV & OPEN & FD & INV \\
\hline GDPC & $2.47 * * *$ & $-.29 * * *$ & ----- & $-.308 * * *$ & $.36 * * *$ & $.79 * * *$ & ------ \\
& $(.93)$ & $(.03)$ & & $(.06)$ & $(.10)$ & $(.09)$ & \\
\hline SAV & $-7.2 * * *$ & $-.146^{*}$ & $.79 * * *$ & ---- & $-1.6 * * *$ & --- & $1.14 * * *$ \\
& $(2.56)$ & $(.08)$ & $(.23)$ & & $(.23)$ & & $(.09)$ \\
\hline
\end{tabular}

Figures in parentheses are standard error. $\mathrm{R}^{2}: 0.64$ and 0.69 for equation one and two and the symbols $* * *, * * *$ indicate significant at $1 \%, 5 \%$, and $10 \%$ levels respectively.

Table 2. System dynamic panel-data estimation

\begin{tabular}{|c|c|c|c|c|c|c|c|c|}
\hline & Constant & $\begin{array}{l}\text { Lagged } \\
\text { variable }\end{array}$ & AID & GDPC & SAV & OPEN & FD & INV \\
\hline GDPC & $\begin{array}{l}-1.54 * * * \\
(.32)\end{array}$ & $\begin{array}{l}.839 * * * \\
(.03)\end{array}$ & $\begin{array}{l}-.02 * * \\
(.01)\end{array}$ & ----- & $\begin{array}{l}-.33 * * \\
(.014) \\
\end{array}$ & $\begin{array}{l}.147 * * * \\
(.034)\end{array}$ & $\begin{array}{l}.044 * \\
(.024) \\
\end{array}$ & ----- \\
\hline \multicolumn{7}{|c|}{ H0: overidentifying restrictions are valid } & $248.39 *$ & \\
\hline SAV & $\begin{array}{l}-1.7 \\
(1.07) \\
\end{array}$ & $\begin{array}{l}.64 * * * \\
(.04)\end{array}$ & $\begin{array}{l}.16^{* * * *} \\
(.027)\end{array}$ & $\begin{array}{l}.148 * * \\
(.064)\end{array}$ & ---- & $\begin{array}{l}-.4 * * * \\
(.1)\end{array}$ & ---- & $\begin{array}{l}.51 * * * \\
(.073)\end{array}$ \\
\hline \multicolumn{7}{|c|}{ H0: overidentifying restrictions are valid } & \multicolumn{2}{|c|}{$212.87 * * *$} \\
\hline
\end{tabular}

Figures in parentheses are standard error. Symbols $* * *, * *, *$ indicate significant at $1 \%, 5 \%$, and $10 \%$ levels respectively.

Table 2 shows the dynamic panel data system analysis; these results are in line with the simultaneous analysis. The results show that foreign aid has a negative effect on growth and domestic savings, at $5 \%$ and $1 \%$ respectively. The results imply that a $1 \%$ increase in foreign aid is estimated to decrease growth by $0.02 \%$ and reduce domestic savings by $0.16 \%$ in the eight MENA countries (Morocco, Algeria, Egypt, Palestine, Syria, Jordan, Lebanon and Tunisia). These findings strongly support the previous results that aid does not supplement 
domestic saving. In addition, increasing aid which increasing imports from donors, Sabra, (2013), which increases openness, which related negatively with saving as shown in model two results. Finally, Sargant test shows that all moment restrictions are satisfied for the dynamic specifications can't be rejected. This means that the instruments are valid, model is robust and correctly specified.

\section{Conclusion}

A great amount of empirical studies has examined the relation between economic growth and its determinants for developing countries and the findings are varied and inconclusive. Aid effectiveness is a controversial subject of debate and the general perception that foreign aid has been ineffective in promoting growth which has led to foreign aid weariness in many donor countries. This study investigates the impact of foreign aid on growth and domestic savings using a simultaneous equation system, besides dynamic panel data system analysis. The result of this study is that foreign aid has a negative effect on economic growth in eight MENA countries (Morocco, Algeria, Egypt, Palestine, Syria, Jordan, Lebanon and Tunisia) using panel data for the period 1977 to 2013. In addition, we have examined the relationships between economic growth, trade openness, domestic investment and fiscal discipline for these countries. Our findings show a negative relationship between domestic savings and economic growth in the presence of foreign aid, which also has a negative effect on growth. Foreign aid seems to crowd out domestic savings rather than complementing it. Domestic savings negative impact on growth may represent the bad connection with investment (it might finance low productive investments) or it might represent money (savings) smuggled abroad. The negative impact of foreign aid on economic growth could be due to a bad policy environment. In addition, foreign aid is less useful for countries with very low levels of human capital, where a big portion of foreign aid received by these countries is used largely to meet humanitarian relief rather than increasing production capacities. The results show positive relationships between economic growth and trade openness. Based on the findings of the study, the policymakers might carry out a policy structure aimed at growing domestic savings, which might lessen dependence on foreign aid. The savings can be employed for human development and increase production capacity. In addition, greater involvement in international trade will enhance economic growth. Finally, results are limited to the considered scenarios.

\section{Future Research}

This work shows the importance of examining empirically the impact of aid as an important international capital inflow on macroeconomic variables such as economic growth and domestic savings. This suggests examining the impact of other international capital inflow such as remittances and foreign direct investment on similar macroeconomic variables.

\section{References}

Arellano, M., \& Bond, S. (1991). Some tests of specification for panel data: Monte Carlo evidence and an application to employment equations. The review of economic studies, 58(2), 277-297. http://dx.doi.org/10.2307/2297968 
Arellano, M., \& Bover, O. (1995). Another Look at the Instrumental-Variable Estimation of Error-Components Models. Journal of Econometrics, 68, 29-51. http://dx.doi.org/10.1016/0304-4076(94)01642-D

Arellano, M., \& Bond, S. (1998). Dynamic Panel Data Estimation using DPD98 for GAUSS. mimeo, Institute for Fiscal Studies, London.

Balde, Y. (2011). The Impact of Remittances and Foreign Aid on Savings/Investment in Sub-Saharan Africa. African Development Review, 23(2), 247-262. http://dx.doi.org/10.1111/j.1467-8268.2011.00284.x

Barro, R. J. (1990). Government Spending in a Simple Model of Endogenous Growth. Journal of Political Economy, 98(5 pt 2). http://dx.doi.org/10.1086/261726

Basnet, H. C. (2013). Foreign aid, domestic savings, and economic growth in South Asia. International Business \& Economics Research Journal (IBER), 12(11), 1389-1394. http://dx.doi.org/10.19030/iber.v12i11.8176

Blundell, R., \& Bond S. (1998). Initial Conditions and Moment Restrictions in Dynamic Panel Data Models. Journal of Econometrics, 87, 115-143. http://dx.doi.org/10.1016/S0304-4076(98)00009-8

Burke, P. J., \& Ahmadi-Esfahani, F. Z. (2006). Aid and growth: A study of South East Asia. Journal of Asian Economics, 17(2), 350-362. http://dx.doi.org/10.1016/j.asieco.2006.02.006

Burnside, C., \& Dollar, D. (2000). Aid, growth, the incentive regime, and poverty reduction. The World Bank: Structure and Policies, $3,210$. http://dx.doi.org/10.1017/CBO9780511560002.009

Chowdhury, A., \& Garonna, P. (2007). Effective foreign aid, economic integration and subsidiarity: Lessons from Europe. CASE Network Studies and Analyses, (346). http://dx.doi.org/10.2139/ssrn.1436909

Chong, A., Gradstein, M., \& Calderon, C. (2009). Can foreign aid reduce income inequality and poverty?. Public Choice, 140(1-2), 59-84. http://dx.doi.org/10.1007/s11127-009-9412-4

Dalgaard, C. J., Hansen, H., \& Tarp, F. (2004). On the empirics of foreign aid and growth. The Economic Journal, 114(496), F191-F216. http://dx.doi.org/10.1111/j.1468-0297.2004.00219.x

Djankov, S., Garcia-Montalvo, J., \& Reynal-Querol, M. (2006). Does foreign aid help?. Available at SSRN 896550. http://dx.doi.org/10.2139/ssrn.896550

Fayissa, B., \& El-Kaissy, M. I. (1999). Foreign aid and the economic growth of developing countries (LDCs): Further evidence. Studies in Comparative International Development, 34(3), 37-50. http://dx.doi.org/10.1007/BF02687626

Griffin, K. (1970). Foreign capital, domestic savings and economic development. Oxford $\begin{array}{llll}\text { Bulletin of Economics and Statistics, } & \text { 55, }\end{array}$ http://dx.doi.org/10.1111/j.1468-0084.1970.mp32002002.x 
Gupta, K. L., \& Islam, M. A. (1982). Foreign capital, savings and growth: An international cross-section study (Vol. 9). D Reidel Publishing Company. http://dx.doi.org/10.1007/978-94-009-7885-0

Hadjimichael, M, Ghura, D., Mühleisen, M., \& Nord, R. (1995). Sub-Saharan Africa: growth, savings, and investment, 1986-93 (Vol. 118). International Monetary Fund.

McGillivray, M., Feeny, S., Hermes, N., \& R. Lensink (2006). Controversies over the impact of development aid: it works; it doesn't; it can, but that depends. Journal of International Development, 18(7), 1031-1050. http://dx.doi.org/10.1002/jid.1335

Mitze, T., \& RWI, E. (2010). Estimating gravity models of international trade with correlated time fixed regressors: To IV or not IV?. Munich Personal RePEc Archive, MPRA Paper o, 23540, 26.

Morrissey, O. (2001). Does aid increase growth?. Progress in Development Studies, 11(1), 37-50. http://dx.doi.org/10.1177/146499340100100104

Murshed, M., \& Khanaum, M. M. (2014). Impact of Foreign Aid in the Economic Development of Recipient Country. Journal of the Bangladesh Association of Young Researchers, 2(1), 33-37. http://dx.doi.org/10.3329/jbayr.v2i1.20539

Neanidis, K., and Varvarigos, D., (2005). The Impact of Foreign Aid on Economic Growth: Volatility of Disbursements and Distribution of Receipts. Centre for Growth and Business Cycle Research, Economic Studies, University of Manchester, UK.

Papanek, G. F. (1973). Aid, foreign private investment, savings, and growth in less developed countries. The Journal of Political Economy, 120-130. http://dx.doi.org/10.1086/260009

Rajan, R., \& Subramanian, A. (2008). Aid and growth: What does the cross-country evidence really show?. The Review of economics and Statistics, 90(4), 643-665. http://dx.doi.org/10.1162/rest.90.4.643

Sabra, M. M. (2013). Does Aid Promote Donor Exports: An Application on the Arab MENA Countries. University of Palestine Review for studies and researches, 4, 1-18, University of Palestine-Gaza, Palestine.

Sabra, M. M., \& Sartawi, S. (2015). Development Impacts of Foreign Aid on Economic Growth, Domestic Savings and Dutch Disease Presence in Palestine. International Journal of Economics and Empirical Research. 3(11), 532-542.

World Bank, (2014). World Development Indicators database, Washington, DC.

\section{Copyright Disclaimer}

Copyright for this article is retained by the author(s), with first publication rights granted to the journal.

This is an open-access article distributed under the terms and conditions of the Creative 
Commons Attribution license (http://creativecommons.org/licenses/by/3.0/). 